\title{
Article \\ Hurdle Effects of Ethanolic Plant Extracts with Antimicrobials Commonly Used in Food against Foodborne Pathogenic Escherichia coli
}

\author{
Waraporn Kusalaruk ${ }^{1,2, *(D)}$ and Hiroyuki Nakano ${ }^{1}$ \\ 1 Laboratory of Food Microbiology and Hygiene, Department of Biofunctional Science and Technology, \\ Graduate School of Biosphere Science, Hiroshima University, Hiroshima 739-8528, Japan; \\ hnakano@hiroshima-u.ac.jp \\ 2 Department of Food Safety, School of Agriculture and Natural Resources, University of Phayao, \\ Phayao 56000, Thailand \\ * Correspondence: d182913@hiroshima-u.ac.jp or ohiohsk@gmail.com
}

Citation: Kusalaruk, W.; Nakano, H. Hurdle Effects of Ethanolic Plant Extracts with Antimicrobials Commonly Used in Food against Foodborne Pathogenic Escherichia coli. Microbiol. Res. 2021, 12, 288-298. https://doi.org/10.3390/ microbiolres 12020020

Academic Editor: Yiannis Kourkoutas

Received: 8 February 2021

Accepted: 31 March 2021

Published: 2 April 2021

Publisher's Note: MDPI stays neutral with regard to jurisdictional claims in published maps and institutional affiliations.

Copyright: (c) 2021 by the authors. Licensee MDPI, Basel, Switzerland. This article is an open access article distributed under the terms and conditions of the Creative Commons Attribution (CC BY) license (https:/ / creativecommons.org/licenses/by/ $4.0 /)$.

\begin{abstract}
Escherichia coli (E. coli) O157:H7 is a major foodborne pathogen that causes severe human infections. Plant extracts, glycine, and sodium acetate (NaOAc) exert antimicrobial effects that can be used to control pathogenic E. coli. However, their combinations have not been investigated. Thus, this study investigates the combination of ethanolic plant extracts with glycine and NaOAc against E. coli at various $\mathrm{pH}$ and temperature levels. Clove and rosemary extracts exhibited significant $(p \leq 0.05)$ antimicrobial activity against $E$. coli. At neutral $\mathrm{pH}$, the combination of plant extracts with $1.0 \%$ glycine or $0.1 \% \mathrm{NaOAc}$ reduced the minimum inhibitory concentration of clove from $0.4 \%$ to $0.2 \%$; at $\mathrm{pH} 5.5$, clove $(0.1 \%)$ and rosemary $(0.2 \%)$ extracts supplemented with $\mathrm{NaOAc}(0.1 \%)$ showed an additive effect. The population of E. coli O157:H7 in phosphate-buffered saline with $0.2 \%$ clove extract, $2 \%$ glycine, and $2 \% \mathrm{NaOAc}$ showed a more than $5 \log$ reduction after incubation at $15{ }^{\circ} \mathrm{C}$ for $96 \mathrm{~h}$, while the combination of $0.1 \%$ clove extract with $2 \% \mathrm{NaOAc}$ at $\mathrm{pH} 5.5$ completely inhibited E. coli within $24 \mathrm{~h}$ at $35^{\circ} \mathrm{C}$. Thus, the combination of plant extracts with glycine and $\mathrm{NaOAc}$ could serve as a promising hurdle technology in controlling the growth of E. coli.
\end{abstract}

Keywords: E. coli O157:H7; antimicrobial activity; plant extract; sodium acetate; glycine; hurdle technology

\section{Introduction}

Escherichia coli (E. coli) O157:H7 is implicated in many foodborne illness outbreaks in countries across the globe. In the last decade, outbreaks associated with E. coli O157:H7 have been commonly traced to food products including beef, leafy greens, and salads [1]. Typically, pathogens in food products are inhibited by the chemical preservative. Nowadays, consumer demand for more natural foods has pressured manufacturers to use natural antimicrobials. Among them, plant extracts have been seen potential use as a direct food antimicrobial, and they may also improve food product quality. For instance, the physicochemical and rheological properties of yoghurt were improved after supplementation with herbal extracts [2]. Clove (Syzygium aromaticum L.), rosemary (Rosmarinus officinalis L.), cinnamon (Cinnamomum verum L.), and liquorice (Glycyrrhiza glabra L.) extracts had inhibitory activity against foodborne pathogens including E. coli [3]. However, some studies reported that E. coli was resistant to spice and herb extracts [4,5]. In this regard, using plant extract to control E. coli might be used at high concentrations, which can negatively affect the sensory quality of food products. To address these challenges, hurdle technology is recommended in order to control this microorganism while maintaining the quality characteristics of food products. Hurdle technology refers to the use of combined methods that can additively or synergistically inactivate microbes, thereby resulting in safe, stable, and tasty foods [6]. Some of the combination methods to control microorganisms include heat treatment with 
an antimicrobial agent [7] or natural antimicrobial with nanotechnology [8]. Antimicrobial agents that may be combined with plant extracts include glycine and sodium acetate $(\mathrm{NaOAc})$, which are generally recognized as safe (GRAS) for human consumption. Glycine is the smallest amino acid that can be used as a nonspecific antiseptic agent due to its low toxicity in animals [9]. On the other hand, $\mathrm{NaOAc}$ is an organic acid salt that is widely available and economical. NaOAc has been used to control microbial growth in meat and bakery products [10,11], and it is generally considered safe to use at low concentrations [12]. There is considerable research investigating the antimicrobial activities of plant extracts against $E$. coli $[5,13,14]$. However, to the authors' knowledge, there is no published study investigating the combined use of plant extracts with glycine and NaOAc. Accordingly, the aim of this study was to determine the antimicrobial activities of 22 plant extracts against foodborne pathogenic E. coli. Furthermore, this study investigates the potential hurdle-technology application of plant extracts with glycine and $\mathrm{NaOAc}$ at different $\mathrm{pH}$ and incubation-temperature levels.

\section{Materials and Methods}

\subsection{Bacterial Strains and Preparation}

The strains tested in this study were a nonpathogenic strain of E. coli (IFO 3301) and two clinical O157:H7 strains (HCIPH 92655 and 96256) obtained from the Hiroshima City Institute of Public Health (HCIPH), Japan. Staphylococcus aureus (S. aureus) 209P and Bacillus cereus (B. cereus) IFO 3457 from our laboratory stock were also used for the comparison between Gram-negative and Gram-positive bacteria. For working-culture preparation, a single colony on a nutrient agar (NA; Eiken Chemical Co., Ltd., Tokyo, Japan) plate was then transferred into a nutrient broth (NB; Eiken Chemical Co., Ltd., Tokyo, Japan) and incubated at $35^{\circ} \mathrm{C}$ for $24 \mathrm{~h}$.

\subsection{Plant-Extract Preparation}

Twenty-two plant extracts were tested for antimicrobial activities (Table 1). Herbs and spices were purchased from the local market of Higashi-Hiroshima, Japan and Accra, Ghana. Extraction was performed in a ratio of 1:9 w/v. Briefly, the plant part or powder was weighed and mixed with nine times the volume of ethanol (99.5\%, Nacalai Tesque, Inc., Kyoto, Japan) and shaken at room temperature for $48 \mathrm{~h}$. Suspensions were centrifuged at $14,430 \times g$ for $30 \mathrm{~min}$ at $4{ }^{\circ} \mathrm{C}$. The supernatant was regarded as $10 \%$ concentration solution and stored at $4{ }^{\circ} \mathrm{C}$ until use.

\subsection{Gas Chromatography-Mass Spectroscopy (GC-MS) Analysis}

The analysis of ethanolic plant extract was performed using GC-MS model JMST100GCV “AccuTOF GCv 4G" (JEOL Ltd., Tokyo, Japan). The column (HP5) was fused with silica $30 \mathrm{~m} \times 0.25 \mathrm{~mm}$ diameter and $0.25 \mu \mathrm{m}$ film thickness. Temperatures were set at $250{ }^{\circ} \mathrm{C}$ for the ion source and $300{ }^{\circ} \mathrm{C}$ for the injector. Helium was used as the carrier gas. The sample $(1 \mu \mathrm{L})$ was evaporated into a split ratio $10: 1$ injector at $300^{\circ} \mathrm{C}$. The temperature of the GC oven was programmed from 50 to $150{ }^{\circ} \mathrm{C}$, held isothermally for $10 \mathrm{~min}$ and, lastly, raised to $300^{\circ} \mathrm{C}$ at $10^{\circ} \mathrm{C} / \mathrm{min}$. Mass-spectrum GC-MS interpretation was performed using the National Institute Standard and Technology Database (NIST).

\subsection{Screening of Plant Extracts for Antimicrobial Activity}

Antimicrobial plant extracts were screened by the disk-diffusion method. Five $\mathrm{mL}$ of molten NA mixed with $100 \mu \mathrm{L}$ of overnight culture (approx. $10^{8} \mathrm{CFU} / \mathrm{mL}$ ) was poured on $10 \mathrm{~mL}$ of a NA basal layer. Paper disks $(8 \mathrm{~mm}$ diameter, $1 \mathrm{~mm}$ thickness, Advantec, Toyo Roshi Co., Ltd., Tokyo, Japan) were then loaded with $50 \mu \mathrm{L}$ of plant extracts and placed onto the surface of the seeded agar. Plates were then kept at $10^{\circ} \mathrm{C}$ for $2 \mathrm{~h}$ to allow for the diffusion of the plant extracts to the agar before incubation at $35^{\circ} \mathrm{C}$ for $24 \mathrm{~h}$. Negative control was a disk containing ethanol $(50 \mu \mathrm{L})$. Antimicrobial activity was determined by measuring the diameter ( $\mathrm{mm}$ ) of the inhibition zone (DIZ). Three independent runs 
with two replicates per run were conducted, and results were presented as mean $\pm \mathrm{SD}$. Plant extracts with potential antimicrobial activities were further used in subsequent minimum inhibitory concentration (MIC) and minimum bactericidal concentration (MBC) determination studies.

Table 1. Plants tested in this study.

\begin{tabular}{ccc}
\hline Scientific Name & Common Name & Part \\
\hline Cinnamomum verum & Cinnamon & Bark \\
Syzygium aromaticum & Clove & Flower bud \\
Helichrysum italicum & Curry plant & Leaves \\
Corymbia citriodora & Lemon eucalyptus & Leaves \\
Glycyrrhiza glabra & Liquorice & Root \\
Myristica fragrans & Mace & Seed coat \\
Myristica fragrans & Nutmeg & Seed \\
Rosmarinus officinalis & Rosemary & Leaves \\
Salvia officinalis & Sage & Leaves \\
Mentha spicaaand & Spearmint & Leaves \\
Thymus vulgaris & Thyme & Leaves \\
Monodora myristica & Calabash nutmeg & Seed \\
Piper guineense & West African black pepper & Seed \\
Tetrepleura tetraptera & Aidan & Fruit \\
Afaramomun melegueta & Grains of paradise & Seed \\
Xylopia aethiopica & Negro pepper & Fruit \\
Pimpenella anisum & Aniseed & Seed \\
Rauvolfia vomitoria & Rauvolfia & Root \\
Parkia biglobosa & African locust bean & Seed \\
Piper nigrum & Black pepper & Seed \\
Capsicum annuum & Cayenne & Fruit \\
Ocimum basilicum & Sweet basil & Leaves \\
\hline
\end{tabular}

\subsection{MIC and MBC Determination}

MIC was determined using agar-dilution method following the method described by Cui et al. [15]. Ethanolic plant extract (10\% solution) was mixed with sterilized NA to final concentrations of $0.1 \%, 0.2 \%, 0.4 \%, 0.6 \%$, and $0.8 \%$. Glycine or NaOAc (Wako Pure Chemical Industries, Ltd., Osaka, Japan) was added to the media at varying levels of 1\%, $2 \%$, $4 \%, 6 \%$, and $8 \%$ before sterilization. Negative control plates including ethanol and distilled water were also prepared. An enriched NB culture content of approximately $10^{8} \mathrm{CFU} / \mathrm{mL}$ was streaked on the surface of agar before being incubated at $35^{\circ} \mathrm{C}$ for $24 \mathrm{~h}$. MIC was determined as the lowest concentration of antimicrobial agents that showed complete inhibition. For MBC determination, broth-dilution method was conducted according to Kim et al. [16] with some adjustments. Briefly, sterilized NB (10 mL) were individually supplemented with varying concentrations of antimicrobial agents. The control tube was substituted by ethanol $(\max 8 \%)$. The tubes were then inoculated with $100 \mu \mathrm{L}$ of the enriched NB cultures. After $24 \mathrm{~h}$ incubation at $35^{\circ} \mathrm{C}$, a loopful of the nonvisible growth $\mathrm{NB}$ was streaked onto NA plates and incubated at $35^{\circ} \mathrm{C}$ for $24 \mathrm{~h}$. MBC was determined as the lowest concentration of antimicrobials with no colonies, as confirmed in the agar plates. MIC and MBC determination was conducted in three independent experiments.

\subsection{Combined Effect of Plant Extracts with Glycine and $\mathrm{NaOAc}$}

Glycine and NaOAc were individually supplemented to NA at levels of $1 \%, 2 \%$, and $0.1 \%, 0.2 \%$, respectively, $\mathrm{pH}$ was adjusted to 5.5 and 7.0 by $10 \% \mathrm{HCl}$ before sterilization. To investigate the hurdle effect of plant extracts with glycine and $\mathrm{NaOAc}$, subinhibitory levels (below MIC) of clove and rosemary extracts were added to the sterilized NA. Negative control containing an equal amount of ethanol $(\max 4 \%)$ was also prepared. Plates were then streaked with an overnight culture (approx. $10^{8} \mathrm{CFU} / \mathrm{mL}$ ) and incubated at $35^{\circ} \mathrm{C}$ for $24 \mathrm{~h}$. The combined effects of plant extract (A) with antimicrobials (B) were determined 
by calculating the fractional inhibitory concentration (FIC) according to the following equation [17]:

FIC index $=\frac{\text { MIC of A when used in combination }}{\text { MIC of A when used alone }}+\frac{\text { MIC of B when used in combination }}{\text { MIC of B when used alone }}$

Combined activities were interpreted and classified according to the range of FIC indices. It was interpreted as synergistic when FIC $<0.5$, additive when $0.5 \leq \mathrm{FIC} \leq 1.0$, absent when $1.0<$ FIC $<2.0$, and antagonistic when FIC $\geq 2.0$.

2.7. Effect of Individual and Combined Clove Extract with Antimicrobials on Survival of E. coli O157:H7 in Phosphate-Buffered Saline (PBS) under Different $p H$ and Incubation-Temperature Levels

The survival of E. coli in PBS with individual clove extract $(0.1 \%$ or $0.2 \%)$, glycine $(2 \%)$, or $\mathrm{NaOAc}(2 \%)$, and the combinations of clove extract with these antimicrobials was established. Cells were harvested by centrifuging $1 \mathrm{~mL}$ of NB suspension at $10,000 \times g$ for $10 \mathrm{~min}$ at room temperature. Pelleted cells were washed twice with sterile PBS and resuspended in $1 \mathrm{~mL}$ PBS as an inoculum. Fifty microliters of inoculum were added to $50 \mathrm{~mL}$ of PBS to initial count of approximately $5.0 \mathrm{log} \mathrm{CFU} / \mathrm{mL}$ under neutral (pH 7.4) or mildly acidic ( $\mathrm{pH} 5.5) \mathrm{pH}$. All samples were then statically incubated at 15 or $35^{\circ} \mathrm{C}$. Sampling time for bacterial enumeration was $0,24,48$, and $96 \mathrm{~h}$ for samples at $15^{\circ} \mathrm{C}$, and $0,12,24,48$, and $96 \mathrm{~h}$ for those at $35^{\circ} \mathrm{C}$. Tenfold serial dilution of the samples was spread-plated onto NA and incubated at $35^{\circ} \mathrm{C}$ for $24 \mathrm{~h}$ prior to counting colonies.

\subsection{Statistical Analysis}

All experiments were carried out in three independent replications. Results of the DIZ of plant extracts and bacterial population were subjected to one-way analysis of variance (ANOVA) using SPSS 25.0 software (IBM, New York, NY, USA). Significant differences among the mean values of treatments were determined by Duncan's multiple-range test (DMRT) at a $95 \%$ level of confidence.

\section{Results and Discussion}

\subsection{Chemical Composition of Plant Extracts}

The chromatogram of the ethanolic clove and rosemary extracts by GC-MS is shown in Figure 1.

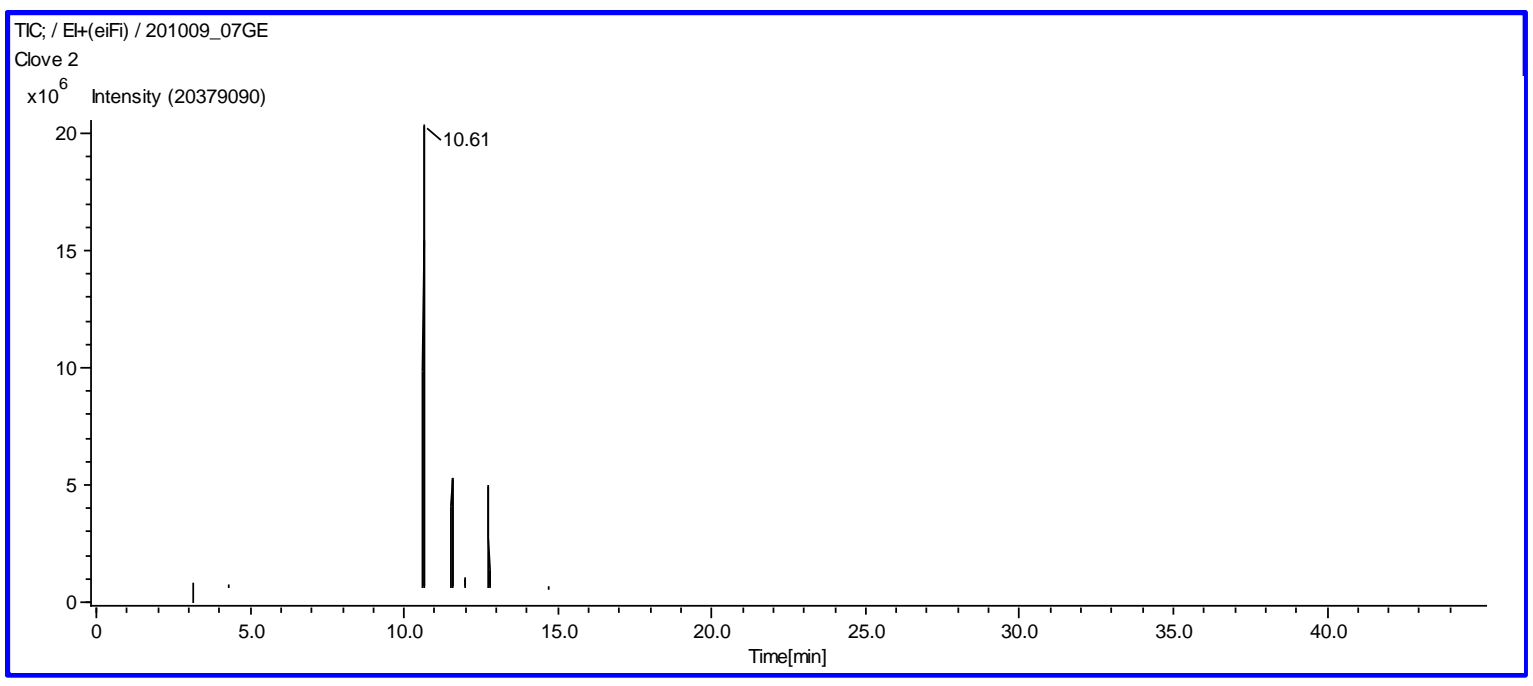

(A) Clove extract

Figure 1. Cont. 


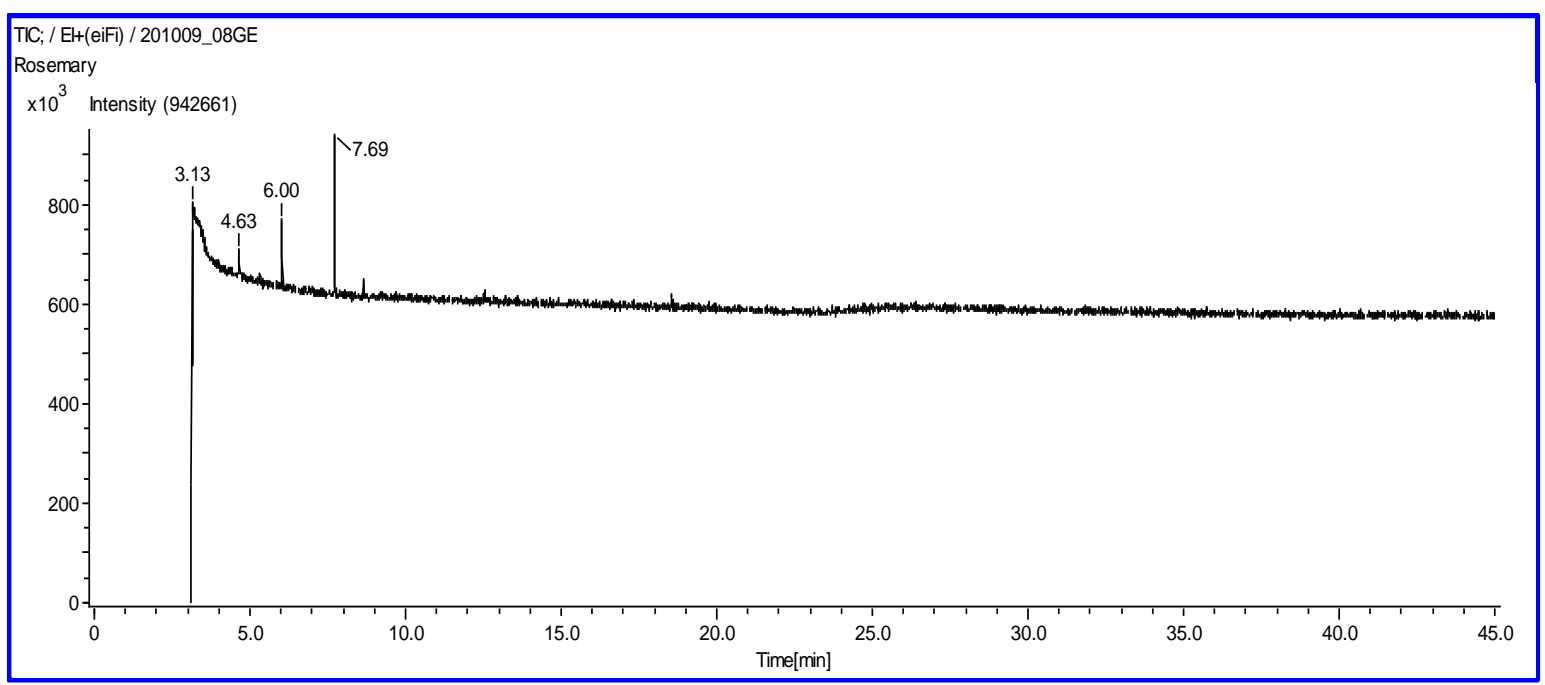

(B) Rosemary extract

Figure 1. GC-MS chromatogram of ethanolic clove (A) and rosemary (B) extracts.

The main chemical components in clove extract were found to be eugenol (63.73\%), caryophyllene (13.97\%), and phenol, 2-methoxy-4-(2-propenyl)-, acetate (12.72\%), while glycidol (67.98\%), 1-isopropyl-4-methylbicyclo [3.1.0] hex-2-ene (4.66\%), eucalyptol (6.14\%), and camphor $(17.15 \%)$ were found in rosemary extract (Table 2$)$.

Table 2. The main chemical compositions of ethanolic plant extracts used in this study.

\begin{tabular}{ccccc}
\hline Plant Extract & RT & Identified Compound & Molecular Formula & Peak Area (\%) \\
\hline Clove & 10.61 & Eugenol & $\mathrm{C}_{10} \mathrm{H}_{12} \mathrm{O}_{2}$ & 63.73 \\
& 11.52 & Caryophyllene & $\mathrm{C}_{15} \mathrm{H}_{24}$ & 13.97 \\
& 12.72 & Phenol, 2-methoxy-4-(2-propenyl)-, acetate & $\mathrm{C}_{12} \mathrm{H}_{14} \mathrm{O}_{3}$ & 12.72 \\
\hline \multirow{2}{*}{ Rosemary } & 3.13 & Glycidol & $\mathrm{C}_{3} \mathrm{H}_{6} \mathrm{O}_{2}$ & 67.98 \\
& 4.63 & 1-Isopropyl-4-methylbicyclo[3.1.0]hex-2-ene & $\mathrm{C}_{10} \mathrm{H}_{16}$ & 4.66 \\
& 6.00 & Eucalyptol & $\mathrm{C}_{10} \mathrm{H}_{18} \mathrm{O}$ & 6.14 \\
& 7.69 & Camphor & $\mathrm{C}_{10} \mathrm{H}_{16} \mathrm{O}$ & 17.15 \\
\hline
\end{tabular}

RT = Retention time, the composition expressed as percentage of the total peak area of the chromatograms.

The main active ingredient of clove extract was similar to that previously reported by Alshaikh and Perveen [18], which showed that eugenol (ca. 75\%) was the main component of clove extract. However, the main compounds of rosemary extract in this study were different from those in previous studies. Moreno et al. [19] showed that the main components in rosemary extract were carnosic acid (30.5\%), rosmarinic acid (5.5\%), and carnosol (16.2\%), while Rašković et al. [20] reported that 1,8-cineole (43.77\%), camphor $(12.53 \%)$, and $\alpha$-pinene $(11.51 \%)$ were the main components of rosemary. The major plant component might be different by cultivar, plant source, or extraction procedure.

\subsection{Antimicrobial Activities of Plant Extracts against Tested Bacteria}

The antimicrobial activities of 22 plant extracts against Gram-negative E. coli and Gram-positive $S$. aureus and B. cereus were investigated and results are presented in Table 3. Significant $(p \leq 0.05)$ antimicrobial activities of ethanolic clove and rosemary extracts against pathogenic and nonpathogenic E. coli, with inhibition zones ranging from 11.25 to $17.25 \mathrm{~mm}$, were observed, while Gram-positive bacteria S. aureus and B. cereus were susceptible to most of the plant extracts. This might be explained by the fact that the Gram-negative cell wall is composed of hydrophobic lipopolysaccharide layers acting as barrier against antimicrobial agents, while the cell wall of Gram-positive bacteria is not as 
complex as that of Gram-negative bacteria [4]. This difference in cell wall structure resulted in the higher susceptibility of the tested Gram-positive bacteria to the administered plant extracts. No inhibition zone in any of the tested strains was observed in the negative control sample. Following the DIZ result, only clove and rosemary extracts were used for MIC and MBC determination against E. coli.

Table 3. Antibacterial activity of ethanolic plant extracts by disk-diffusion method against E. coli.

\begin{tabular}{|c|c|c|c|c|c|}
\hline \multirow{3}{*}{ Plant Extract } & \multicolumn{5}{|c|}{ Diameter of Inhibition Zone ${ }^{1}$ (mm) } \\
\hline & \multirow{2}{*}{$\begin{array}{c}\text { E. coli } \\
\text { IFO } 3301\end{array}$} & \multicolumn{2}{|c|}{ E. coli 0157:H7 } & \multirow{2}{*}{$\frac{\text { S. aureus }}{209 \mathrm{P}}$} & \multirow{2}{*}{$\begin{array}{l}\text { B. cereus } \\
\text { IFO } 3457\end{array}$} \\
\hline & & HCIPH 92655 & НСIPH 92656 & & \\
\hline Clove & $13.0 \pm 0.8^{a}$ & $12.2 \pm 0.5^{\mathrm{a}}$ & $17.2 \pm 1.9^{\mathrm{a}}$ & $19.0 \pm 1.4^{b}$ & $11.0 \pm 0^{\mathrm{d}}$ \\
\hline Curry plant & $8.0 \pm 0.0^{\mathrm{c}}$ & $8.0 \pm 0.0^{b}$ & $8.0 \pm 0.0^{c}$ & $33.5 \pm 2.1^{\mathrm{a}}$ & $22.0 \pm 1.4^{\mathrm{a}}$ \\
\hline Lemon eucalyptus & $8.2 \pm 0.5^{c}$ & $8.0 \pm 0.0^{b}$ & $8.0 \pm 0.0^{c}$ & $14.5 \pm 0.7^{\mathrm{d}, \mathrm{e}, \mathrm{f}}$ & $12.0 \pm 0.0^{\mathrm{c}}$ \\
\hline Liquorice & $8.0 \pm 0.0^{c}$ & $8.0 \pm 0.0^{b}$ & $8.0 \pm 0.0^{c}$ & $15.0 \pm 0.0^{\mathrm{d}, \mathrm{e}}$ & $9.5 \pm 0.7^{\mathrm{e}}$ \\
\hline Mace & $8.0 \pm 0.0^{c}$ & $8.0 \pm 0.0^{b}$ & $8.0 \pm 0.0^{c}$ & $18.5 \pm 2.1^{b c}$ & $11.0 \pm 0.0^{\mathrm{d}}$ \\
\hline Nutmeg & $8.0 \pm 0.0^{c}$ & $8.0 \pm 0.0^{b}$ & $8.0 \pm 0.0^{\mathrm{c}}$ & $12.5 \pm 0.7^{\mathrm{f}, \mathrm{g}}$ & $8.0 \pm 0.0^{\mathrm{f}}$ \\
\hline Rosemary & $11.2 \pm 1.0^{b}$ & $11.8 \pm 1.0^{\mathrm{a}}$ & $12.0 \pm 0.0^{b}$ & $13.5 \pm 0.7^{\mathrm{e}, \mathrm{f}, \mathrm{g}}$ & $8.0 \pm 0.0^{\mathrm{f}}$ \\
\hline Sage & $8.0 \pm 0.0^{\mathrm{c}}$ & $8.0 \pm 0.0^{b}$ & $8.0 \pm 0.0^{\mathrm{c}}$ & $16.5 \pm 0.0^{\mathrm{c}, \mathrm{d}}$ & $11.5 \pm 0.7^{\mathrm{c}, \mathrm{d}}$ \\
\hline Thyme & $8.0 \pm 0.0^{c}$ & $8.0 \pm 0.0^{b}$ & $8.0 \pm 0.0^{c}$ & $19.5 \pm 0.7^{\mathrm{b}}$ & $8.0 \pm 0.0^{\mathrm{f}}$ \\
\hline Calabash nutmeg & $8.0 \pm 0.0^{\mathrm{c}}$ & $8.0 \pm 0.0^{b}$ & $8.0 \pm 0.0^{c}$ & $17.5 \pm 0.7^{b, c}$ & $12.0 \pm 0.0^{\mathrm{c}}$ \\
\hline Grains of paradise & $8.0 \pm 0.0^{\mathrm{c}}$ & $8.0 \pm 0.0^{b}$ & $8.0 \pm 0.0^{c}$ & $12.0 \pm 0.0^{\mathrm{g}}$ & $8.0 \pm 0.0^{\mathrm{f}}$ \\
\hline Negro pepper & $8.0 \pm 0.0^{\mathrm{c}}$ & $8.0 \pm 0.0^{b}$ & $8.0 \pm 0.0^{c}$ & $13.5 \pm 0.7^{\mathrm{e}, \mathrm{f}, \mathrm{g}}$ & $16.5 \pm 0.7^{b}$ \\
\hline Aniseed & $8.0 \pm 0.0^{\mathrm{c}}$ & $8.0 \pm 0.0^{b}$ & $8.0 \pm 0.0^{c}$ & $11.5 \pm 0.7^{g}$ & $8.0 \pm 0.0^{f}$ \\
\hline African locust bean & $8.0 \pm 0.0^{c}$ & $8.0 \pm 0.0^{b}$ & $8.0 \pm 0.0^{c}$ & $18.5 \pm 2.1^{b, c}$ & $11.5 \pm 0.7^{\mathrm{c}, \mathrm{d}}$ \\
\hline Sweet basil & $8.0 \pm 0.0^{\mathrm{c}}$ & $8.0 \pm 0.0^{b}$ & $8.0 \pm 0.0^{\mathrm{c}}$ & $12.5 \pm 0.7^{\mathrm{f}, \mathrm{g}}$ & $8.0 \pm 0.0^{\mathrm{f}}$ \\
\hline Control (ethanol) & $8.0 \pm 0.0^{c}$ & $8.0 \pm 0.0^{b}$ & $8.0 \pm 0.0^{c}$ & $8.0 \pm 0.0^{h}$ & $8.0 \pm 0.0^{\mathrm{f}}$ \\
\hline
\end{tabular}

Cinnamon, spearmint, west African black pepper, aidan, rauvolfia, black pepper, and cayenne did not show antibacterial activity against all test strains. ${ }^{1}$ Average of 2 values from 3 independent runs shown as mean \pm SD. Disk diameter of 8.0 mm. ${ }^{a, b, c, d, e, f, g, h}$ Values in the same column with the same superscript are not significantly different $(p>0.05)$.

\subsection{MIC and MBC of Plant Extracts against E. coli}

The MIC and MBC values of the plant extracts and antimicrobials at neutral condition are shown in Table 4 . MIC and MBC of $0.4 \%$ were observed in ethanolic clove extract, which was lower compared to the MIC of the ethanolic clove extract $(1.0 \%)$ reported by Pundir et al. [13]. For rosemary extracts, MIC and MBC were $0.6 \%$ and $0.8 \%$, respectively, which agreed with Kayira and Nakano [21] who reported that the MIC and MBC of ethanolic rosemary extracts against $E$. coli was $>0.4 \%$. The efficacy of plant extracts against bacteria could be attributed to their phenolic compounds [22]. The different efficacy levels on antimicrobial activity of clove and rosemary extracts in this study could be attributed to the differences in their major constituents. No inhibitory activity against E. coli was observed in the negative-control sample ( $8 \%$ ethanol).

On the basis of previous studies, the plant-extract mechanism on microorganisms was reported with various explanations. Some studies reported that the plant extract could mainly destroy the cell walls and membranes of microorganisms, permeate the cytoplasmic membranes or enter the cells, and then change the cell metabolism [23]. Another study reported that thymol inactivated E. coli by disrupting the function of the plasma membrane by decreasing intracellular ATP and increasing extracellular ATP, while cinnamaldehyde in cinnamon inhibits cell wall biosynthesis, membrane function, and some enzymes [24].

In terms of glycine, MICs were $4 \%$ in all tested strains. Similarly, the MICs of NaOAc were $4 \%$ for both strains of pathogenic E. coli, while $6 \%$ was inhibitory for nonpathogenic E. coli (Table 4). Another study reported the MIC of glycine and $\mathrm{NaOAc}$ as $4 \%$ and $>0.8 \%$, respectively against $E$. coli [21]. The use of plant extracts in food might require greater concentrations than those determined in in vitro studies due to the food matrix being complex $[25,26]$. This might result in adverse effects on the sensory quality of the food 
product. Thus, the application of hurdles to reduce the higher concentration of plant extracts was investigated for controlling bacteria.

Table 4. Minimum inhibitory concentration (MIC) and minimum bactericidal concentration (MBC) of plant extracts and antimicrobial agents against pathogenic and non-pathogenic E. coli at neutral $\mathrm{pH}$.

\begin{tabular}{ccccc}
\hline \multirow{2}{*}{ Compounds } & & \multicolumn{3}{c}{ Concentration (\%) } \\
\cline { 3 - 5 } & & E. coli & \multicolumn{2}{c}{ E. coli O157:H7 } \\
\cline { 3 - 5 } & & IFO 3310 & HCIPH 92655 & HCIPH 92656 \\
\hline Clove Extract & MIC & 0.4 & 0.4 & 0.4 \\
& MBC & 0.4 & 0.4 & 0.4 \\
\hline Rosemary Extract & MIC & 0.6 & 0.6 & 0.6 \\
& MBC & 0.8 & 0.8 & 0.8 \\
\hline Glycine & MIC & 4.0 & 4.0 & 4.0 \\
& MBC & 4.0 & 4.0 & 4.0 \\
\hline Sodium Acetate & MIC & 6.0 & 4.0 & 4.0 \\
& MBC & 8.0 & 8.0 & 8.0 \\
\hline
\end{tabular}

MIC and MBC assays were replicated at least 3 times.

\subsection{Effect of Glycine or $\mathrm{NaOAc}$ on Antibacterial Activity of Plant Extracts against E. coli in Neutral and Mildly Acidic Media}

The antimicrobial activities of clove or rosemary extract individually supplemented with glycine or NaOAc against $E$. coli in neutral and mildly acidic conditions are shown in Table 5. Initially, the individual MIC of the plant extracts under different $\mathrm{pH}$ were determined. The efficacy of the antimicrobial activities of clove extract was increased under mildly acidic $\mathrm{pH}$ as observed through the reduction of its MIC from $0.4 \%$ to $0.2 \%$, while there was no change in the rosemary extract. In the current study, stronger inhibitory activity was observed by clove extract than rosemary extract, and may thus offer good compatibility when used with other types of hurdles. The reduced MIC of clove to $0.2 \%$ in neutral media was observed when either $0.1 \%$ or $0.2 \% \mathrm{NaOAc}$ was supplemented but had no effect on the MIC of rosemary extract $(0.6 \%)$. In weakly acidic media (pH 5.5$)$, further reduction in the MICs of clove and rosemary to $0.1 \%$ and $0.2 \%$, respectively, was observed when $\mathrm{NaOAc}$ at $0.1 \%$ or $0.2 \%$ was added. At $0.1 \%$ and $0.2 \% \mathrm{NaOAc}$ supplementation, FIC indices for clove extract indicating additive antimicrobial activity were calculated to be 0.53 and 0.55 , respectively. This additive interaction remained unchanged even at mildly acidic conditions (0.70 and 0.90). For rosemary extract, the FIC indices that were calculated to be at 1.03 and 1.05 for $0.1 \%$ and $0.2 \%$ NaOAc supplementation, respectively, indicated no interactive effects between rosemary extract and $\mathrm{NaOAc}$. However, in mildly acidic media, FIC indices decreased, ranging from 0.53 to 0.73 , indicating positive additive interaction. A low $\mathrm{pH}$ condition possibly be suitable for plant extracts and $\mathrm{NaOAc}$ to penetrate cells, resulting in the observed additive interaction.

Table 5. Combined effects of ethanolic plant extracts with antimicrobials.

\begin{tabular}{|c|c|c|c|c|c|c|c|c|c|c|c|c|c|c|c|c|c|c|}
\hline \multirow{4}{*}{ Plant Extract } & \multicolumn{2}{|c|}{$\underset{(\%)}{\text { Individual MIC }}$} & \multicolumn{8}{|c|}{ MIC When Combined with Antimicrobials (\%) } & \multicolumn{8}{|c|}{ FIC Index ${ }^{1}$} \\
\hline & \multirow{3}{*}{ pH 7.0 } & \multirow{3}{*}{ pH 5.5} & \multicolumn{4}{|c|}{ pH 7.0} & \multicolumn{4}{|c|}{ pH 5.5} & \multicolumn{4}{|c|}{ pH 7.0} & \multicolumn{4}{|c|}{ pH 5.5} \\
\hline & & & \multicolumn{2}{|c|}{ NaOAc } & \multicolumn{2}{|c|}{ Glycine } & \multicolumn{2}{|c|}{$\mathrm{NaOAc}$} & \multicolumn{2}{|c|}{ Glycine } & \multicolumn{2}{|c|}{ NaOAc } & \multicolumn{2}{|c|}{ Glycine } & \multicolumn{2}{|c|}{ NaOAc } & \multicolumn{2}{|c|}{ Glycine } \\
\hline & & & 0.1 & 0.2 & 1.0 & 2.0 & 0.1 & 0.2 & 1.0 & 2.0 & 0.1 & 0.2 & 1.0 & 2.0 & 0.1 & 0.2 & 1.0 & 2.0 \\
\hline Clove & 0.4 & 0.2 & 0.2 & 0.2 & 0.2 & 0.2 & 0.1 & 0.1 & 0.2 & 0.2 & 0.53 & 0.55 & 0.75 & 1.00 & 0.70 & 0.90 & 1.25 & 1.50 \\
\hline Rosemary & 0.6 & 0.6 & $0 . \overline{6}$ & $0 . \overline{6}$ & $0 . \overline{6}$ & 0.4 & 0.2 & 0.2 & $0 . \overline{6}$ & $0 . \overline{6}$ & 1.03 & 1.05 & 1.25 & 1.17 & 0.53 & 0.73 & 1.25 & 1.50 \\
\hline
\end{tabular}


In neutral media, MIC reduction in clove extract to $0.2 \%$ was facilitated by supplementing $1 \%$ glycine but had no further influence in weakly acidic media. In terms of rosemary extract, supplementing with $1 \%$ glycine also did not produce any improved effect in both neutral and weakly acidic media. However, increasing the supplementation level to $2 \%$ reduced the MIC of rosemary from $0.6 \%$ to $0.4 \%$ in neutral media, while the MIC of rosemary in weakly acidic media remained unchanged. FIC indices for the combined activities of clove or rosemary extracts with glycine in neutral media were also calculated to evaluate their efficacy. For clove extract supplemented with glycine at $1 \%$ and $2 \%$, their additive antimicrobial activity could be observed in their calculated FIC indices at 0.75 and 1.00, respectively (Table 5). This agrees with Minami et al. [9], who reported that the combination of glycine and amoxicillin showed higher antimicrobial activity against Gram-negative Helicobacter pylori as compared to when glycine or amoxicillin was used alone. For the rosemary extract, the calculated FIC indices at pH 7.0 were 1.25 and 1.17, implying no interactive effect with glycine supplementations at $1 \%$ and $2 \%$, respectively. Furthermore, in mildly acidic media, the FIC indices for both clove and rosemary extracts with glycine indicated no interaction, with FIC indices of 1.25 and 1.50 (Table 5). This could be explained by the fact that glycine exists as a neutral amino acid, but when environmental $\mathrm{pH}$ shifts into an acidic condition, its functional properties could be changed [27].

\subsection{Combined Effects of Clove Extract and Antimicrobials on E. coli O157:H7 in PBS under Different $\mathrm{pH}$ and Incubation-Temperature Levels}

In the current report, clove extract had higher efficacy against $E$. coli than that of rosemary extract; thus, it was used in this part. Figure $2 \mathrm{~A}$ shows incubation at $35^{\circ} \mathrm{C}$ under neutral and mildly acidic conditions. Under neutral $\mathrm{pH}$, approximately $3 \log$ reduction was exhibited by the individual supplementation of $0.1 \%$ clove extract or $2 \%$ glycine, while adding $2 \% \mathrm{NaOAc}$ and the control sample $(1 \% \mathrm{EtOH})$ did not significantly $(p>0.05)$ change the bacterial population after $96 \mathrm{~h}$. The highest inhibitory activity against $E$. coli O157:H7 was approximately $3.5 \log$ reduction after $24 \mathrm{~h}$, and complete inhibition after $48 \mathrm{~h}$ was observed with combination of $0.1 \%$ clove extract $+2 \%$ glycine, and $0.1 \%$ clove extract $+2 \%$ glycine $+2 \% \mathrm{NaOAc}$. In the sample containing $0.1 \%$ clove extract $+2 \% \mathrm{NaOAc}$, the E. coli population gradually decreased from $5.52 \pm 0.04$ to $1.43 \pm 0.32 \log \mathrm{CFU} / \mathrm{mL}$ after $96 \mathrm{~h}$. For weakly acidic conditions, decrease in the bacterial count by approximately $2 \log$ reduction after $96 \mathrm{~h}$ was found in the individual clove extract $(0.1 \%)$, glycine $(2 \%)$, or NaOAc (2\%). Significant population reduction of more than $5 \log \mathrm{CFU} / \mathrm{mL}$ after $24 \mathrm{~h}$ was observed in the combination of $0.1 \%$ clove extract with $2 \% \mathrm{NaOAc}$, as well as the sample containing $0.1 \%$ clove extract $+2 \%$ glycine $+2 \% \mathrm{NaOAc}$. This result apparently agrees with that of Ehsani et al. [28], who reported that the combination of essential oil with $\mathrm{NaOAc}$ at $\mathrm{pH} 5.0$ reduced the population of bacteria and extended the shelf life of fish burgers. Adding $0.1 \%$ clove extract with $2 \%$ glycine gradually decreased the population until $24 \mathrm{~h}$, and significantly $(p \leq 0.05)$ decreased it after $48 \mathrm{~h}$, while the population of the control sample remained approximately $5 \log \mathrm{CFU} / \mathrm{mL}$ after $96 \mathrm{~h}$. For incubation at $15^{\circ} \mathrm{C}$, no significant $(p>0.05)$ change in the bacterial population was seen in individual $2 \%$ glycine or NaOAc, similar to that of the control sample (approx. $5 \log \mathrm{CFU} / \mathrm{mL}$ ); $0.2 \%$ clove extract gradually reduced the number of $E$. coli O157:H7 under both $\mathrm{pH}$ levels (7.4 and 5.5). However, when clove extract $(0.2 \%)$ was used alone, population reduction to the lower detection limit $(<10 \mathrm{CFU} / \mathrm{mL})$ was not attained after $96 \mathrm{~h}$. The highest efficacy against $E$. coli O157:H7 was exhibited by the combination of clove extract with glycine and $\mathrm{NaOAc}$ and was complete inhibition after $96 \mathrm{~h}$. In addition, strong antimicrobial activity was shown in the combination of $0.2 \%$ clove extract with $2 \%$ glycine or NaOAc compared to using individual factors under both neutral and mildly acidic conditions (Figure 2B). 
pH 7.4
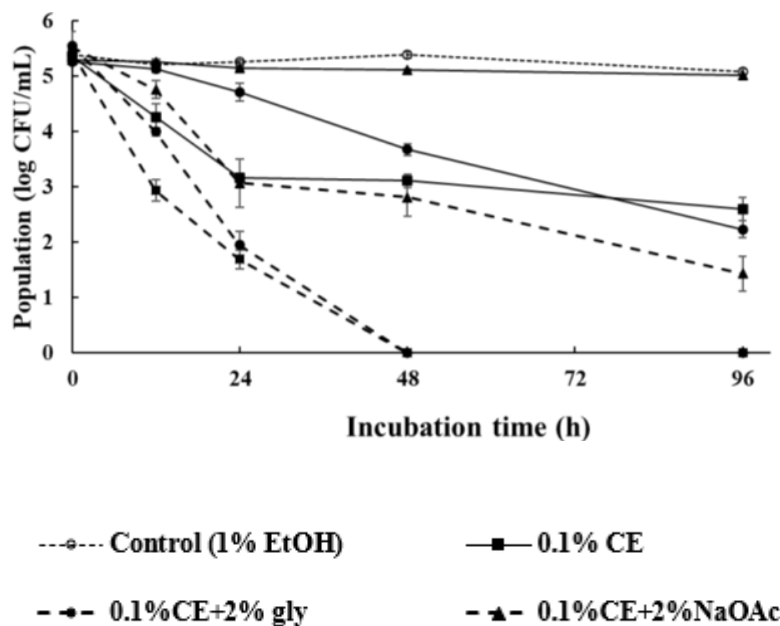

pH 5.5
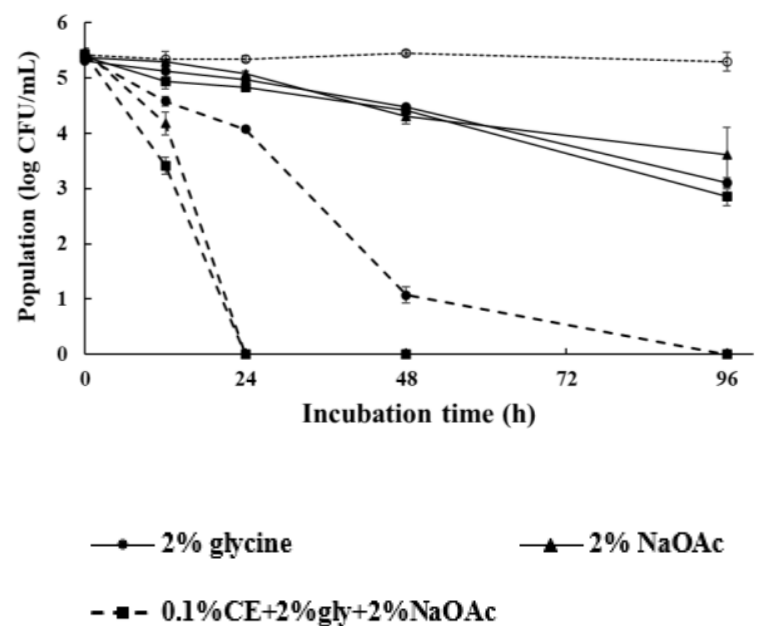

$\mathrm{pH} 7.4$
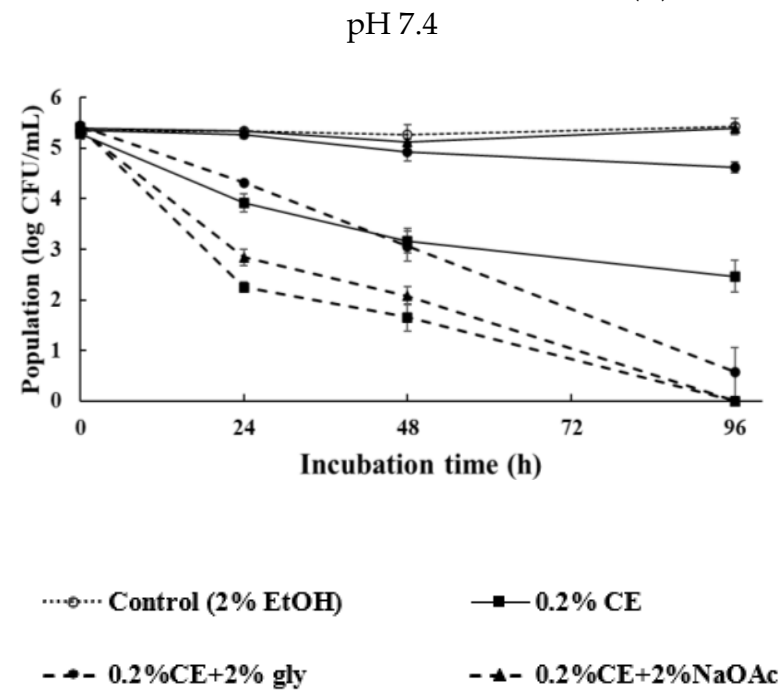

(B) Incubation at $15{ }^{\circ} \mathrm{C}$

pH 5.5

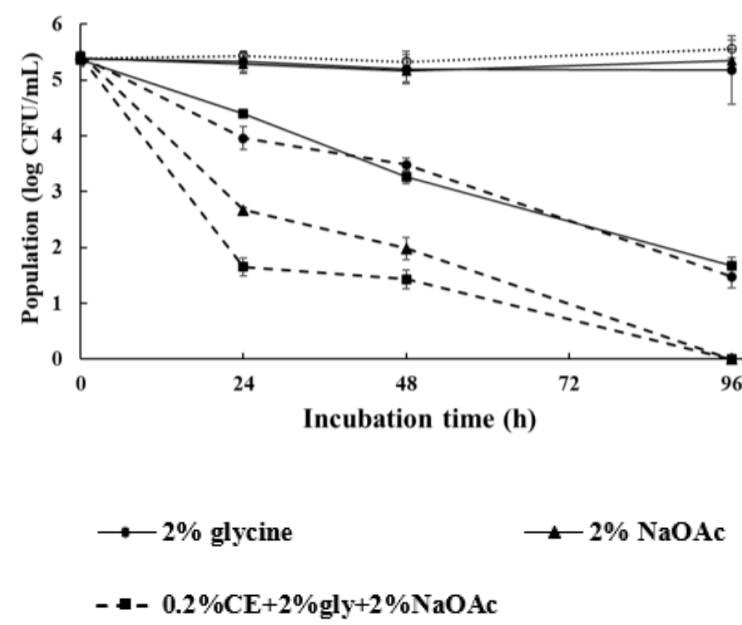

Figure 2. The survival of E. coli O157:H7 in PBS containing individual and/or in combination of clove extract, glycine, and $\mathrm{NaOAc}$ incubated at (A) $35^{\circ} \mathrm{C}$ and (B) $15^{\circ} \mathrm{C}$; pH 7.4 (left side) and pH 5.5 (right side). Values of each treatment are mean $\pm \mathrm{SD}(\mathrm{n}=3)$.

Thus, using clove extract with glycine and/or NaOAc showed higher potential to reduce the population of E. coli O157:H7 as compared to when an individual factor was used. Furthermore, clove extract could be used at sub-MIC when used in combined factors. The observation in this study could be explained by the fact that glycine might inhibit cell wall synthesis and disrupt the membranes, while clove extract disintegrates the outer membrane of bacteria, which could allow for $\mathrm{NaOAc}$ to permeate the cell membrane and dissociate inside the cell $[9,29]$. Under these stress conditions, the bacteria cannot overcome the hurdles, which leads to their injury or death.

On the basis of the results of this study, E. coli O157:H7 incubated at $15{ }^{\circ} \mathrm{C}$ was more resistant to antimicrobial agents than that incubated at $35^{\circ} \mathrm{C}$ regardless of $\mathrm{pH}$ condition. Similar observations were reported in previous studies, whereby the addition of plant extracts or essential oils in foods decreased antimicrobial activity at lower storagetemperature levels against foodborne pathogens as compared to that in higher temperature levels [30-32]. This behavior might be because temperature has effect on the growth of bacteria. In the growth curve of E. coli O157:H7, lag time increased, but the growth rate 
decreased when temperature decreased [33]. The inactivation of E. coli under unfavorable conditions possibly be more difficult than that in conditions where the metabolism is active. However, combined factors used in this study inactivated pathogenic E. coli even at such adverse conditions.

\section{Conclusions}

In this study, the activity of various antimicrobial agents against $E$. coli at varying concentrations demonstrated their potential application in hurdle technology. Additive effects were observed in samples treated with clove extract and glycine at neutral $\mathrm{pH}$, and clove or rosemary extract with $\mathrm{NaOAc}$ at mildly acidic $\mathrm{pH}$. The combination of clove extract with glycine and $\mathrm{NaOAc}$ showed the highest inhibitory activity against E. coli O157:H7 by a population reduction of more than $5 \log$ CFU/mL under both neutral and mildly acidic conditions. At $15{ }^{\circ} \mathrm{C}$ incubation temperature, E. coli O157:H7 showed more resistance to antimicrobials than when incubated at $35^{\circ} \mathrm{C}$. However, using the combined technique of clove extract with glycine and $\mathrm{NaOAc}$ demonstrated inhibitory activity against pathogenic E. coli. Thus, the idea of hurdle technology applied in the current study could serve as a promising strategy in controlling pathogenic bacteria. Since variations in the chemical composition of plant extracts from different sources and different food matrices can affect the antimicrobial activity, future studies are necessary to determine the optimum antimicrobial conditions for practical application of plant extracts in mildly acidic foods at room temperature.

Author Contributions: W.K.: Designed and conducted experiments, and wrote original manuscript; H.N.: reviewed and edited manuscript. All authors have read and agreed to the published version of the manuscript.

Funding: This work was supported by the Royal Thai Government. All authors have provided consent.

Informed Consent Statement: Not applicable.

Conflicts of Interest: The authors declare no conflict of interest.

\section{References}

1. Center for Desease Control and Prevention (CDC). Available online: https://www.cdc.gov/ecoli/outbreaks.html (accessed on 3 December 2020).

2. Dabija, A.; Codină, G.G.; Ropciuc, S.; Gâtlan, A.-M.; Rusu, L. Assessment of the Antioxidant Activity and Quality Attributes of Yogurt Enhanced with Wild Herbs Extracts. J. Food Qual. 2018, 2018, 1-12. [CrossRef]

3. Zhang, H.; Kong, B.; Xiong, Y.L.; Sun, X. Antimicrobial Activities of Spice Extracts against Pathogenic and Spoilage Bacteria in Modified Atmosphere Packaged Fresh Pork and Vacuum Packaged Ham Slices Stored at $4{ }^{\circ}$ C. Meat Sci. 2009, 81, 686-692. [CrossRef] [PubMed]

4. Shan, B.; Cai, Y.-Z.; Brooks, J.D.; Corke, H. The in vitro Antibacterial Activity of Dietary Spice and Medicinal Herb Extracts. Int. J. Food Microbiol. 2007, 117, 112-119. [CrossRef]

5. Mostafa, A.A.; Al-Askar, A.A.; Almaary, K.S.; Dawoud, T.M.; Sholkamy, E.N.; Bakri, M.M. Antimicrobial Activity of Some Plant Extracts against Bacterial Strains Causing Food Poisoning Diseases. Saudi J. Biol. Sci. 2018, 25, 361-366. [CrossRef] [PubMed]

6. Leistner, L.; Gorris, L.G.M. Food Preservation by Hurdle Technology. Trends Food Sci. Technol. 1995, 6, 41-46. [CrossRef]

7. Gurtler, J.B.; Fan, X.; Jin, T.; Niemira, B.A. Influence of Antimicrobial Agents on the Thermal Sensitivity of Foodborne Pathogens: A Review. J. Food Prot. 2019, 82, 628-644. [CrossRef] [PubMed]

8. Cacciatore, F.A.; Brandelli, A.; Malheiros, P.D.S. Combining Natural Antimicrobials and Nanotechnology for Disinfecting Food Surfaces and Control Microbial Biofilm Formation. Crit. Rev. Food Sci. Nutr. 2020, 1-12. [CrossRef] [PubMed]

9. Minami, M.; Ando, T.; Hashikawa, S.; Torii, K.; Hasegawa, T.; Israel, D.A.; Ina, K.; Kusugami, K.; Goto, H.; Ohta, M. Effect of Glycine on Helicobacter pylori in vitro. Antimicrob. Agents Chemother. 2004, 48, 3782-3788. [CrossRef]

10. Sallam, K.H.I.; Samejima, K. Microbiological and Chemical Quality of Ground Beef Treated with Sodium Lactate and Sodium Chloride during Refrigerated Storage. LWT Food Sci. Technol. 2004, 37, 865-871. [CrossRef] [PubMed]

11. Smith, J.P.; Daifas, D.P.; El-Khoury, W.; Koukoutsis, J.; El-Khoury, A. Shelf Life and Safety Concerns of Bakery Products-a Review. Crit. Rev. Food Sci. Nutr. 2004, 44, 19-55. [CrossRef]

12. Mohammadzadeh-Aghdash, H.; Sohrabi, Y.; Mohammadi, A.; Shanehbandi, D.; Dehghan, P.; Dolatabadi, J.E.N. Safety Assessment of Sodium Acetate, Sodium Diacetate and Potassium Sorbate Food Additives. Food Chem. 2018, 257, 211-215. [CrossRef] [PubMed]

13. Pundir, K.R.; Jain, P.; Sharma, C. Antimicrobial Activity of Ethanolic Extracts of Syzygium aromaticum and Allium sativum against Food Associated Bacteria and Fungi. Ethnobot. Leafl. 2010, 14, 334-360. 
14. Weerakkody, N.S.; Caffin, N.; Turner, M.S.; Dykes, G.A. In Vitro Antimicrobial Activity of Less-Utilized Spice and Herb Extracts against Selected Food-Borne Bacteria. Food Control 2010, 21, 1408-1414. [CrossRef]

15. Cui, H.; Gabriel, A.A.; Nakano, H. Antimicrobial Efficacies of Plant Extracts and Sodium Nitrite against Clostridium botulinum. Food Control 2010, 21, 1030-1036. [CrossRef]

16. Kim, J.; Marshall, M.R.; Wei, C. Antibacterial Activity of Some Essential Oil Components against Five Foodborne Pathogens. J. Agric. Food Chem. 1995, 43, 2839-2845. [CrossRef]

17. Sweeney, M.T.; Zurenko, G.E. In Vitro Activities of Linezolid Combined with Other Antimicrobial Agents against Staphylococci, Enterococci, Pneumococci, and Selected Gram-Negative Organisms. Antimicrob. Agents Chemother. 2003, 47, 1902-1906. [CrossRef]

18. Alshaikh, N.; Perveen, K. Anti-Candidal Activity and Chemical Composition of Essential Oil of Clove (Syzygium aromaticum). J. Essent. Oil Bear. Plants 2017, 20, 951-958. [CrossRef]

19. Moreno, S.; Scheyer, T.; Romano, C.S.; Vojnov, A.A. Antioxidant and Antimicrobial Activities of Rosemary Extracts Linked to Their Polyphenol Composition. Free Radic. Res. 2006, 40, 223-231. [CrossRef]

20. Rašković, A.; Milanović, I.; Pavlović, N.; Ćebović, T.; Vukmirović, S.; Mikov, M. Antioxidant Activity of Rosemary (Rosmarinus officinalis L.) Essential Oil and Its Hepatoprotective Potential. BMC Complement. Altern. Med. 2014, 14, 225. [CrossRef]

21. Kayira, T.M.; Nakano, H. Antibacterial Effects of Plant Extracts with Hurdle Technology against Vibrio cholerae. FEMS Microbiol. Lett. 2020, 367, 1-6. [CrossRef]

22. Gutiérrez-del-Río, I.; Fernández, J.; Lombó, F. Plant Nutraceuticals as Antimicrobial Agents in Food Preservation: Terpenoids, Polyphenols and Thiols. Int. J. Antimicrob. Agents 2018, 52, 309-315. [CrossRef] [PubMed]

23. Li, H.-N.; Wang, C.-Y.; Wang, C.-L.; Chou, C.-H.; Leu, Y.-L.; Chen, B.-Y. Antimicrobial Effects and Mechanisms of Ethanol Extracts of Psoralea corylifolia Seeds against Listeria monocytogenes and Methicillin-Resistant Staphylococcus aureus. Foodborne Pathog. Dis. 2019, 16, 573-580. [CrossRef] [PubMed]

24. Gonelimali, F.D.; Lin, J.; Miao, W.; Xuan, J.; Charles, F.; Chen, M.; Hatab, S.R. Antimicrobial Properties and Mechanism of Action of Some Plant Extracts Against Food Pathogens and Spoilage Microorganisms. Front. Microbiol. 2018, 9. [CrossRef] [PubMed]

25. Meira, N.V.B.; Holley, R.A.; Bordin, K.; Macedo, R.E.F.; de Luciano, F.B. Combination of Essential Oil Compounds and Phenolic Acids against Escherichia coli O157:H7 in Vitro and in Dry-Fermented Sausage Production. Int. J. Food Microbiol. 2017, 260 , 59-64. [CrossRef] [PubMed]

26. Smith-Palmer, A.; Stewart, J.; Fyfe, L. The Potential Application of Plant Essential Oils as Natural Food Preservatives in Soft Cheese. Food Microbiol. 2001, 18, 463-470. [CrossRef]

27. Sepahi, M.; Jalal, R.; Mashreghi, M. Antibacterial Activity of Poly-1-Arginine under Different Conditions. Iran. J. Microbiol. 2017, 9, 103-111.

28. Ehsani, A.; Jasour, M.S.; Hashemi, M.; Mehryar, L.; Khodayari, M. Zataria multiflora Boiss Essential Oil and Sodium Acetate: How They Affect Shelf Life of Vacuum-Packaged Trout Burgers. Int. J. Food Sci. Technol. 2014, 49, 1055-1062. [CrossRef]

29. Takahashi, H.; Takahashi, T.; Miya, S.; Yokoyama, H.; Kuda, T.; Kimura, B. Growth Inhibition Effects of Ferulic Acid and Glycine/Sodium Acetate on Listeria monocytogenes in Coleslaw and Egg Salad. Food Control. 2015, 57, 105-109. [CrossRef]

30. Govaris, A.; Solomakos, N.; Pexara, A.; Chatzopoulou, P.S. The Antimicrobial Effect of Oregano Essential Oil, Nisin and Their Combination against Salmonella Enteritidis in Minced Sheep Meat during Refrigerated Storage. Int. J. Food Microbiol. 2010, 137, 175-180. [CrossRef]

31. Kotzekidou, P.; Giannakidis, P.; Boulamatsis, A. Antimicrobial Activity of Some Plant Extracts and Essential Oils against Foodborne Pathogens in Vitro and on the Fate of Inoculated Pathogens in Chocolate. LWT Food Sci. Technol. 2008, 41, 119-127. [CrossRef]

32. Solomakos, N.; Govaris, A.; Koidis, P.; Botsoglou, N. The Antimicrobial Effect of Thyme Essential Oil, Nisin, and Their Combination against Listeria monocytogenes in Minced Beef during Refrigerated Storage. Food Microbiol. 2008, 25, 120-127. [CrossRef] [PubMed]

33. Lee, J.-I.; Kim, S.-S.; Kang, D.-H. Susceptibility of Escherichia coli O157:H7 Grown at Low Temperatures to the Krypton-Chlorine Excilamp. Sci. Rep. 2019, 9, 563. [CrossRef] [PubMed] 